\title{
Research on the Teaching Actual Effect of Ideological and Political Theory Classroom in Higher Vocational Colleges in the New Media
}

\author{
Shu Tao ${ }^{1, a}$ \\ ${ }^{1}$ Wuhan Polytechnic, Wuhan, Hubei, China, 430000 \\ aemail,
}

Keywords: New Media; Vocational Colleges; Ideological and Political Theory; Effectiveness

\begin{abstract}
In order to better adapt to the rapid development of higher vocational education in our country and improve the quality of teaching in colleges and universities, the effectiveness of classroom teaching in ideological and political theory of higher vocational colleges is in line with the teaching rules. The arrival of the new media era has made us see both opportunities and challenges. Based on the characteristics of the new media era and the ideological and political theory classroom teaching in higher vocational colleges, this paper analyzes the current situation of the teaching effectiveness of the course in the new media era, analyzes its existing problems and puts forward some suggestions to improve the effectiveness of classroom teaching.
\end{abstract}

\section{Introduction}

With the development of the times technology, mobile media, blog, blog, digital TV as the representative of the means of communication and tools gradually replaced the traditional newspapers, radio, television media communication form, the new media era followed. For the majority of young people, especially students, they live in the Internet world, and the image of the "new generation of the network." The development of network technology to give them learning, life has brought great changes, not only for them to provide free exploration channels and opportunities, more importantly to cultivate and change their way of thinking, which is the development of the times and social progress, But at the same time, the convenience of channels and access to information to the juvenile education has brought some challenges in a variety of cultural exchange agitation, tradition and modern cultural integration, they face the choice of values more diverse and complex. The new media era provides a quick and effective teaching channel for the ideological and political theory classroom teaching of our higher vocational colleges, and it is a road that deserves to be explored. How to improve the teaching quality of ideological and political theory classroom teaching in higher vocational colleges according to the characteristics of classroom teaching of ideological and political theory in higher vocational colleges and how to make better use of new media services in teaching? This is the study of this article.

\section{The Vocational Colleges Ideological and Political Theory Classroom Teaching in the New Media Era}

The Concept and the Characteristics of the New Media Times. The use of digital, network, mobile technology, the Internet, wireless communications network, satellite and other channels, through computers, mobile phones, digital TV and other terminals for the media, to provide users with information and entertainment services and media form of media form, we call it for new media or digital media. The core of the new media is the realization of digital information symbol communication technology, which includes four aspects: First, the establishment and development of new media is based on digital and network technology, and second, new media communication with all-weather and geographical. Third, the new media in the product, technology, operations, services and other business models with innovative impact and driving force; Fourth, the new media boundaries in the continuous changes in integration, especially the integration of the media cannot avoid.

The new media emphasizes the integration of audio and video information, the media has the 
characteristics of communication fragmentation, carrying massive information, information communication environment virtualization, such as some music software can be based on your favorite songs, we can see the lyrics and MV, and This is only the initial stage of the development of new media, the latest AR technology is to let people have more personal experience. In the future, we will get more experience and enjoyment, have more options.

At the same time, the interaction is also the unique charm of the new media. Interaction has become the people's daily, including the interaction with television programs, business interaction and interaction between people, such as watching the Spring Festival Evening from our childhood simply to see the TV today to see the red envelope, vote to choose the program and their favorite programs; our discount information on the shopping malls do not need to go shopping to understand as long as the public micro-signal can be concerned about the public; we are no longer only with the stars from the TV point of view, we can concerned about micro-blogging, and then understand his daily life, and thus narrow the distance between the two sides. Internet and other technologies continue to enhance the rapid development of new media influence, the modern media officially entered a new era of anti-off-oriented environment.

The Characteristics of Ideological and Political Theory Classroom Teaching in Higher Vocational Colleges. There are three characteristics in the teaching of ideological and political theory courses in higher vocational colleges: First, the particularity of teaching objects is first manifested in the complicated level of students, including five years of vocational college graduates, vocational graduates, secondary school graduates, high school graduates. Second, the performance of psychological sensitivity of students, more inferiority is the main performance of this psychological, which has become Chinese ideological and political education in urgent need to solve the outstanding problems. From the objective environment, people generally regard higher vocational education as a lower level of education. The final performance of the students in the moral awareness of the disconnect, the students of this period are basically in adolescence, but also our "new generation of the network," the main force, the current network environment is extremely complex, a large number of biased, reactionary, unhealthy remarks And the content is full of the network, they partially reflect the social governance problems and shortcomings, which did not form a reasonable, scientific values, life view of young people have a certain misleading effect. From some of the investigation and monitoring found that some of the adolescent network expression to the extreme speech, and even the formation of a network of violent language; posting the use of radical speech and vulgar language and other performance that adolescents have moral awareness and moral behavior out of touch. Their own psychological immaturity is more susceptible to the bad mood of the new media era, so the correct guidance is more important. Enhancing the Effectiveness of Ideological and Political Theory Classroom Teaching in Higher Vocational Colleges is an Important Way to Realize Correct Guidance. Second, the long-term nature of teaching objectives, ideological and political theory courses to cultivate moral, intellectual, physical, beauty, labor and other aspects of quality personnel have an important role, to establish and cultivate high school students correct outlook on life, values and world view It is an important part of Chinese comprehensive implementation of the strategy of rejuvenating the country through science and education, talent and talent strategy, and the effectiveness of ideological and political theory teaching in higher vocational colleges is an important goal and direction of ideological and political theory course in higher vocational colleges. Third, the teaching environment is challenging. In the new media age, the teaching environment of ideological and political theory course in higher vocational colleges is more complicated and changeable. Students get more information from the new media, more quickly and quickly, but diversify the value orientation, society is more complex, increasingly fierce competition with the new media as the medium of the domestic and foreign awareness and value orientation to the original complex teaching environment is more complex. The conflict between traditional values and intricate social and international situations creates new knowledge and confusion. 


\section{The Status Quo of Higher Vocational Colleges Ideological and Political Theory Classroom Teaching Effectiveness in the New Media Era.}

We have entered the new media era, which is an objective fact. However, the ideological and political theory of higher vocational colleges has not followed the pace of the times, still follow the traditional teaching mode, teaching philosophy and teaching mechanism.

The Present Situation of Ideological and Political Theory Classroom Teaching in Higher Vocational Colleges in the New Media. The so-called "teaching" is the teacher strength, ideological and political theory course teachers need to be further improved is a huge problem, mainly in the teacher's political theory and business quality is not high enough. In the new media era, asked our ideological and political theory teachers not only to master the textbooks in the knowledge, we need to continue to learn to master the new media technology, and guide the correct scientific values. This requires teachers to adhere to the Marxist world outlook, outlook on life, values, adhere to the socialist scientific values, adhere to the party's "three represents", adhere to the scientific concept of development and advancing with the times, but in fact can adhere to the correct values and continuous there are not many teachers to learn. The so-called "learning" is the object of teaching is the student, that is, "the new generation of the network," the main component, they not only exist basic disciplinary issues (late, leave early, absent ), these questions in the ideological and political class performance the more obvious, but also the existence of money worship, exorcism, ignoring the traditional moral and other incorrect values, such as no scruples on the Internet to criticize any person anything, without concealing their own shortcomings, lack of civilization, malicious post, Especially self-centered vocational colleges should take the discipline management of students as the most basic requirements, and to strengthen the correct use of new media for students to conduct scientific guidance.

The Teaching Mode of Higher Vocational Colleges' Ideological and Political Theory Classroom Teaching the New Media Era Is Traditional and Machinery, the Effectiveness of Practical Teaching Is Mainly in the Form. Chinese higher vocational colleges ideological and political theory classroom teaching and teaching model is still using spoon-fed education model, that is, examination-oriented education, does not meet the quality of education needs in China. In the vocational colleges, the teacher stood on the podium, the students sitting next to listen to the "one speech" teaching mode is still no change, according to the script, the old board blunt, boring and rigid teaching makes high vocational students tired of school ideological and political theory course. The reform of teaching mode is an urgent problem to be solved in the ideological and political theory classroom teaching of higher vocational colleges in our country.

The evaluation mechanism of ideological and political theory course in higher vocational colleges is unreasonable. Most of the traditional paper version examination methods can only examine the students 'grasp and understanding of the cultural knowledge they can learn, and cannot really reflect and reflect students' practice and cognition and innovation. Practical teaching because there is no basic assessment is only a mere formality does not attach importance to content. Practice teaching links there is no system of protection, especially the lack of financial support, which makes the current form of practice teaching more difficult to carry out. Practice teaching only focus on planning, just appear in the curriculum of students in the vocational school, what is actually done, how to do, what is often no basis to follow, there is no assessment, making practice teaching is not taken seriously, in the students It seems to be optional. In addition to teaching the main teachers and students do not attach importance to, the objective environment is also caused by practical teaching is not important to the important reason. Practice teaching involves students, schools and social practice points in many aspects, the practice of student safety issues, funding, transportation, location, time and so on are restricting the ideological and political theory courses in vocational colleges to carry out practical teaching.

Ideological and Political Theory of Higher Vocational Colleges and Universities Scientific Research Concept Is Obsolete, Single and Lack of Stamina. In the new media era, in the face of rapidly changing situation, to maintain the original way to carry out ideological and political theory 
of scientific research, did not make full use of the convenience of the Internet, despite the continuous enrichment of scientific research, rich, but the scientific form of boring, Research for research makes research lack of fun, and many students forget. In the view of higher vocational students, ideological and political theory of scientific research is "school tyrants" who do the things that are not interested in their attitude towards scientific research. The content of the scientific research does not match the student's needs is another important reason why the students are not interested in the research content and the students daily life and the future work and life is not close. The main reason is the lack of utilization of new media and the school still remains in the traditional form of scientific research. Finally, the overall quality of teachers' scientific research is not high, leading to the deep understanding of ideological and political theory, then the teacher as the main body of ideological and political theory of scientific research is bound to the problem of insufficient stamina, reflected in the ideological and political theory of scientific research innovation is not enough, thoroughly analyze and solve the problems raised in scientific research and so on.

\section{The Recommendations to Enhance the Ideological and Political Theory Classroom Teaching Effectiveness of Vocational Colleges in the New Media Era}

Establish a Scientific Ideological and Political Theory Classroom Teaching Objectives. The ideological goal of the ideological and political theory course in higher vocational colleges is to make the scientific and ideological theory of science "into the teaching materials, into the classroom, into the college students mind", so that Guangfa vocational students through learning, establish and form a scientific theoretical system, doctrine of materialism science world view, methodology applied to the daily life of work, dialectical understanding, analysis and solve the problem, establish a noble ideological and moral sentiment, the formation of good daily behavior norms and healthy correct "three view". So that they face in the new media era brought about by the impact of the diversity of values, to be able to firm belief, not the complexity of the unscientific ideas and value orientation with deviation, so as to better use of the new media era of new media Resources, better exercise self and explore the world. This requires higher vocational schools and ideological and political theory teachers to fully understand the new media era and the characteristics of the new media era to establish a scientific ideological and political theory classroom teaching objectives.

Scientifically Use New Media to Help Achieve Ideological and Political Theory Classroom Teaching Objectives. In the process of ideological and political theory classroom teaching in higher vocational colleges, we should make full use of new media resources, break the traditional teaching mode and evaluation mechanism, combine theory with practice, and bring the practical effect of ideological and political theory classroom teaching. In the teaching mode, you can make full use of new media, such as We-Chat, micro-blogging platform for teaching interaction, the form can be varied, video live conference, video teaching, to promote teaching reform. Another example, in the ideological and political theory of practice teaching, can be achieved through the network and social resources sharing, teaching in practice, in the search for reasonable practice time, place, etc. can make full use of new media resources.

Higher vocational colleges ideological and political theory classroom teaching evaluation mechanism reform can also make full use of new media resources, the ideological and political theory practice is also included in the evaluation mechanism. The evaluation method is no longer limited to the paper version of the simple test, can be a teaching video, practice video or a hot post, so that teaching more interesting and practical, more close to the life of vocational students and the reality. So as to improve the learning interest and enthusiasm of the students in higher vocational colleges, and to enhance the enthusiasm of teachers to guide students to study and form a good teaching interaction, so as to realize the improvement of the effectiveness of ideological and political theory classroom teaching in higher vocational colleges.

\section{Conclusion}

To sum up, in the new media body era, to enhance the ideological and political theory of higher 
vocational colleges classroom teaching effectiveness should be fully reasonable with the new media resources. Through the reform of the classroom teaching mode of the ideological and political theory in higher vocational colleges, we will actively increase the practicality and innovation of the teaching classroom, attach importance to the teaching research, realize the teaching goal and provide the excellent view of the motherland with three views, good moral character and good technology professional talent.

\section{References}

[1] $\mathrm{Li} \mathrm{Xu}$. Based on the network environment of higher vocational colleges ideological and political theory teaching effectiveness of multi-dimensional path research[J]. Youth, 2016 (5): 44-44.

[2] Zhang Dan, Zeng Shu, Xu Jianping. New media age vocational colleges ideological and political theory teaching difficulties and countermeasures [J]. Journal of Xingtai Vocational and Technical College, 2016, 33 (3): 35-37.

[3] Li Dan, Cheng Jia, Wu Shusheng. New media environment under the ideological and political theory of teaching methods[J]. Chengdu Vocational and Technical College Vocational Education Research, 2015 (4): 21-24. 